THE DEVELOPMENT OF SOCIAL SCIENCE LEARNING QUALITY AND OUTPUT EVALUATION MODEL IN JUNIOR SECONDARY SCHOOL

\author{
Sugeng Eko Putro Widoyoko
}

\begin{abstract}
This study aimed at developing Social Science learning evaluation model in Junior Secondary Schools $(\mathrm{N}=736)$. Such a model was called the learning quality and output evaluation model (Model EKOP). Try out was done in Yogyakarta and Central Java provinces. The development process was conducted in three steps; data collection using attitude inventory and rating scale, quantitative and qualitative data analyses, and goodness of fit using the confirmatory factor analysis. The goodness fit of measurement was measured using four indicators, 1) Chi-square; 2) A-value; 3) RMSEA; and 4) GFI. Findings show that a) based on experts, users and educational practitioners, EKOP model is one of the good evaluation models; b) the quality and output evaluation model has fitted the field data; c) the experts, users and practitioners suggested that the evaluation manual is good as the guidelines of the implementation of the EKOP Model.
\end{abstract}

Key words: evaluation model, learning quality, learning output 


\title{
PENGEMBANGAN MODEL EVALUASI KUALITAS DAN OUTPUT PEMBELAJARAN IPS DI SMP
}

\author{
Sugeng Eko Putro Widoyoko
}

\begin{abstract}
Abstrak
Penelitian ini bertujuan untuk mengembangkan model evaluasi program pembelajaran IPS di SMP. Model yang dikembangkan disebut dengan model evaluasi kualitas dan output pembelajaran (model EKOP). Subjek uji coba berjumlah 736 responden. Uji coba dilaksanakan di wilayah propinsi DIY dan Jawa Tengah. Proses pengembangan dilakukan melalui tiga tahap. Pengumpulan data menggunakan metode inventori sikap dan rating scale. Analisis data menggunakan pendekatan kuantitatif dan kualitatif. Analisis kecocokan model pengukuran menggunakan confirmatory factor analysis (CFA). Kecocokan model pengukuran menggunakan empat indikator, yaitu: 1) ChiSquare; 2) @-value; 3) RMSEA; dan 4) GFI. Berdasarkan hasil analisis data dapat disimpulkan bahwa: a) model EKOP merupakan salah satu model evaluasi yang baik. Hal ini didasarkan pada hasil penilaian pakar, pemakai, maupun praktisi pembelajaran IPS; b) model pengukuran kualitas dan output pembelajaran IPS sudah sesuai dengan data lapangan, dan c) hasil penilaian pakar, pemakai, maupun praktisi pembelajaran IPS menunjukkan bahwa panduan evaluasi dinilai cukup baik sebagai acuan implementasi evaluasi model EKOP.
\end{abstract}

Kata kunci: model evaluasi, kualitas pembelajaran, output pembelajaran 


\section{Pendahuluan}

\section{Latar Belakang Masalah}

Salah satu tujuan evaluasi program adalah menghasilkan informasi yang dapat dijadikan sebagai dasar pengambilan keputusan, penyusunan kebijakan, maupun penyusunan program berikutnya. Agar informasi dapat berfungsi secara maksimal, maka informasi yang dihasilkan dari evaluasi program harus komprehensif, valid dan reliabel serta tepat waktu (timely) dalam penyampaian.

Evaluasi dalam bidang pendidikan ditinjau dari sasarannya dapat dibedakan menjadi dua, yaitu evaluasi yang bersifat makro dan yang mikro. Evaluasi yang bersifat makro sasarannya adalah program pendidikan pada umumnya, yaitu program yang direncanakan untuk memperbaiki bidang pendidikan. Evaluasi mikro sering digunakan di tingkat kelas. Jadi sasaran evaluasi mikro adalah program pembelajaran di kelas (Djemari Mardapi. 2000: 2). Guru mempunyai tanggung jawab untuk menyusun dan melaksanakan program pembelajaran di kelas, sedangkan pimpinan sekolah mempunyai tanggung jawab untuk mengevaluasi program pembelajaran yang telah disusun dan dilaksanakan oleh guru.

Berdasarkan survei awal yang dilakukan penulis pada tahun 2007 di SMPN 5 dan SMPN 8 kota Yogyakarta, SMP Muhammadiyah Gamping Sleman dan SMP Muhammadiyah Purworejo dengan responden yang terdiri dari: 6 orang guru IPS, 3 orang kepala sekolah, dan 2 orang wakil kepala sekolah menunjukkan bahwa keberhasilan program pembelajaran IPS selama hanya didasarkan hasil penilaian belajar siswa, sedangkan evaluasi terhadap kualitas pembelajaran IPS kurang mendapat perhatian. Penilaian hasil belajar IPS siswa lebih terfokus pada aspek kecakapan akademik, kurang memperhatikan kecakapan personal maupun kecakapan sosial. Walaupun hasil survei tersebut belum representatif mewakili keseluruhan SMP yang ada di Indonesia, namun, dua temuan tersebut menunjukkan adanya kelemahan evaluasi program pembelajaran IPS yang berjalan selama ini.

Berdasarkan latar belakang di atas diperlukan pengembangan sebuah model evaluasi program pembelajaran IPS di SMP yang lebih 
komprehensif dan mampu memberikan informasi secara lebih tepat bagi guru IPS dan pimpinan sekolah serta bermanfaat optimal untuk meningkatkan program pembelajaran IPS selanjutnya. Istilah informasi yang tepat meliputi: tepat dari segi cakupan, isi informasi, serta tepat dari segi waktu penyampaian informasi tentang program pembelajaran yang sedang maupun telah berjalan. Istilah komprehensif mempunyai makna bahwa cakupan evaluasi tidak hanya pada aspek output saja tetapi mencakup aspek kualitas pembelajaran, output pembelajaran tidak hanya terbatas pada kecakapan akademik (academic skill) tetapi juga mencakup kecakapan personal (personal skill) dan kecakapan sosial (social skill).

\section{Model Evaluasi Kualitas dan Output Pembelajaran (Model EKOP)}

Model ini menggunakan pendekatan evaluasi proses dan hasil. Evaluasi proses pembelajaran dalam hal ini disebut dengan evaluasi kualitas pembelajaran. Penilaian hasil pembelajaran disebut dengan penilaian output pembelajaran, sehingga nama model ini disebut dengan model evaluasi kualitas dan output pembelajaran (model EKOP). Penggunaan istilah output dilandasi asumsi bahwa hasil pembelajaran IPS dapat dibedakan menjadi dua, yaitu output dan outcome. Output terdiri dari kecakapan akademik, kecakapan personal dan kecakapan sosial. Outcome merupakan prestasi siswa dalam masyarakat yang lebih luas dan prestasi di jenjang pendidikan selanjutnya. Penilaian outcome dapat dilakukan melalui penelusuran (tracer) alumni.

Model EKOP merupakan kombinasi antara model CIPP (Contex, Input, Process, Product) dari Stufflebeam, dengan Kirkpatrick evaluation model dengan pengurangan dan perluasan pada beberapa aspek evaluasi. Kombinasi antara CIPP model dengan Kirkpatrick evaluation model difokuskan pada dua hal, yaitu:

a. Level evaluasi. Pada evaluasi model CIPP dari empat aspek program yang ada, yaitu contex, input, process dan product, sedangkan pada model EKOP hanya dilakukan pada dua aspek yaitu proses dan produk yang dalam penelitian ini disebut dengan kualitas pembelajaran dan output pembelajaran. 
b. Cakupan evaluasi kualitas pembelajaran diperluas dibandingkan dengan level reaction. Perluasan ini meliputi penambahan aspek yang dinilai, yang meliputi aspek: kinerja guru dalam kelas, fasilitas belajar, iklim kelas, sikap siswa, dan motivasi belajar siswa. Sedangkan aspek output meliputi kecakapan akademik, kecakapan personal dan kecakapan sosial. Reaction dalam konsep Kirkpatrick dimasukkan dalam iklim kelas. Aspek input walaupun tidak berdiri sendiri sebagai salah satu aspek evaluasi, tetapi terwakili dalam kualitas pembelajaran, yaitu sikap dan motivasi siswa dapat diasumsikan sebagai salah satu representasi aspek input dalam konsep CIPP model, sehingga model EKOP lebih sederhana dalam implementasi dibandingkan model CIPP dan model Kirkpatrick tanpa mengurangi kelengkapan informasi yang dibutuhkan dalam evaluasi sebuah program.

Evaluasi program pembelajaran IPS di SMP model EKOP mempunyai dua komponen utama, yaitu kualitas pembelajaran dan output pembelajaran. Kualitas pembelajaran meliputi aspek: kinerja guru dalam kelas, fasilitas pembelajaran, iklim kelas, sikap dan motivasi belajar siswa. Penilaian fasilitas pembelajaran difokuskan pada pemanfaatan (utility) dari fasilitas yang tersedia. Output pembelajaran meliputi penilaian terhadap kecakapan akademik, kecakapan personal dan kecakapan sosial. Komponen-komponen tersebut dapat diwujudkan dalam bentuk bagan berikut: 


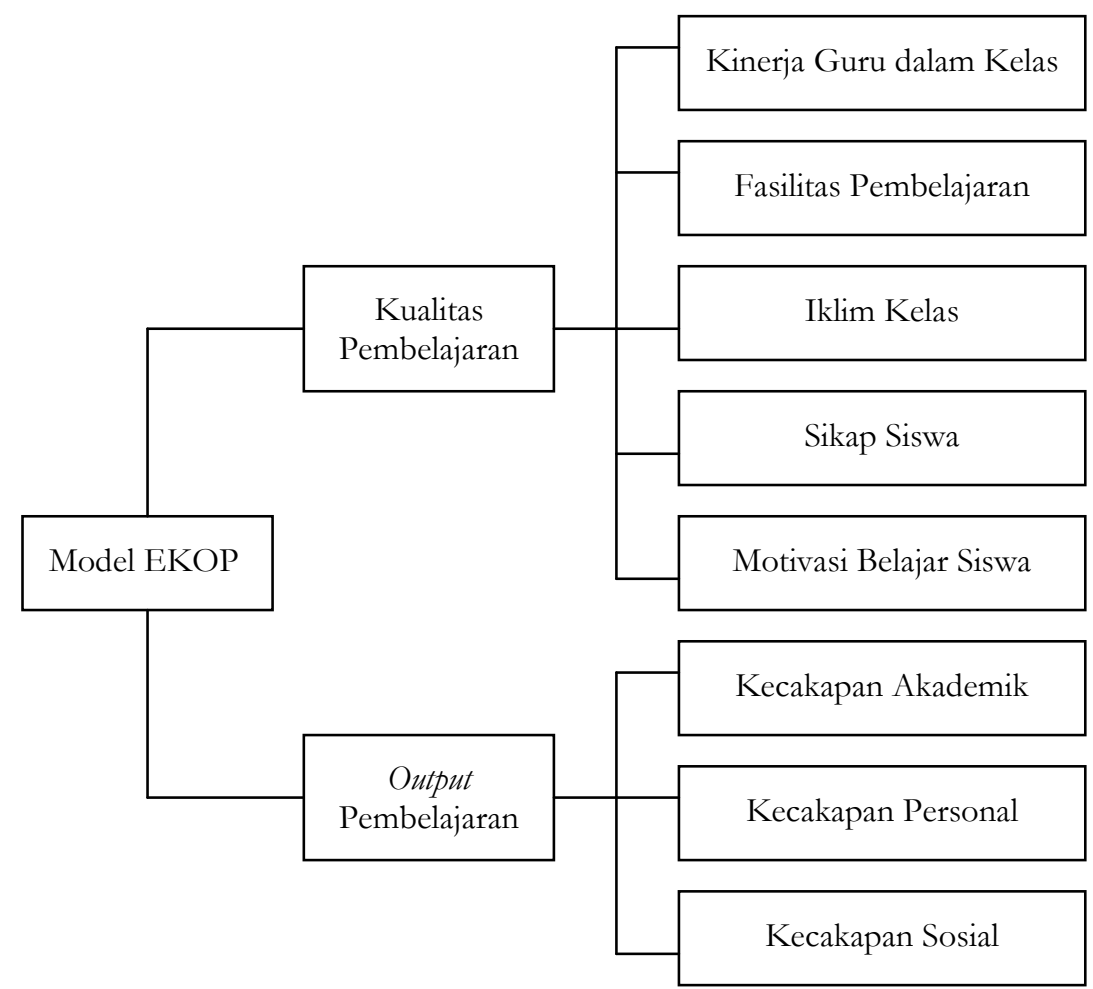

Gambar 1. Komponen-komponen Model EKOP

\section{Metode Penelitian}

\section{Model Penelitian}

Penelitian ini menggunakan model penelitian dan pengembangan (Research \& Development). Adapun model yang digunakan adalah model pengembangan dari Plomp yang dikombinasikan dengan model Borg \& Gall. Pengertian kombinasi dalam hal ini adalah langkah-langkah penelitian dan pengembangan menggunakan acuan pokok dari Plomp, sedangkan penentuan jumlah subjek ujicoba menggunakan acuan dari Borg \& Gall, yaitu jumlah subjek ujicoba dari yang pertama, kedua dan seterusnya semakin meningkat. 
Pengembangan model evaluasi program pembelajaran model EKOP menempuh langkah-langkah: 1) analisis teori dan hasil penelitian sebelumnya, 2) penyusunan desain dan perangkat model evaluasi yang didasarkan pada hasil analisis beragam teori model-model evaluasi program dan hasil-hasil penelitian sebelumnya, 2) validasi pakar (expert judgement), yang dilakukan dengan menggunakan model focus group dicussion (FGD) dan delphi, 3) uji coba produk, 4) analisis data, dan 5) uji implementasi. Pakar atau ahli yang telibat dalam kegiatan FGD terdiri dari 4 orang dosen PPs S3 UNY dengan bidang keahlian masing-masing: pendidikan IPS, pendidikan nilai, metodologi penelitian, dan pengukuran, 9 orang guru IPS SMP dan 3 orang kepala/wakil kepala SMP.

\section{Ujicoba Produk}

Aspek yang divalidasi dalam tahap uji model evaluasi ini meliputi: a) evaluasi model EKOP, b) instrumen evaluasi model EKOP, dan c) panduan evaluasi model EKOP. Ujicoba model dilakukan dalam tiga tahap, yaitu: uji coba tahap pertama, tahap kedua dan tahap ketiga sebagai uji implementasi.

Subjek ujicoba yang terlibat dalam penelitian ini terdiri dari siswa SMP, guru IPS, serta Kepala Sekolah maupun Wakil Kepala Sekolah sebagai representasi dari pimpinan sekolah dan mahasiswa PEP S3. Jumlah subjek ujicoba evaluasi model EKOP dapat dilihat dalam tabel berikut ini.

Tabel 1. Jumlah Subjek Ujicoba Evaluasi Model EKOP

\begin{tabular}{|l|c|c|c|c|}
\hline \multirow{2}{*}{ Subjek Uji coba } & \multicolumn{3}{|c|}{ Uji coba ke } & Jumlah \\
& I & II & III & Total \\
\hline Kepala Sekolah & 2 & 1 & 2 & 5 \\
\hline Wakil Kepala Sekolah & 1 & 2 & 2 & 5 \\
\hline Guru IPS & 5 & 5 & 9 & 19 \\
\hline Siswa SMP & 159 & 222 & 320 & 701 \\
\hline Mahasiswa S3 PEP & 4 & 2 & 0 & 6 \\
\hline \multicolumn{1}{|c|}{ Jumlah } & 171 & 232 & 333 & 736 \\
\hline
\end{tabular}




\section{Pengumpulan dan Analisis Data}

Pengumpulan data menggunakan inventory dan rating scale Instrumen pengumpulan data dianalis dengan CFA (Confirmatory Factor Analysis), model EKOP dianalisis secara deskriptif berdasarkan penilaian guru IPS dan pimpinan sekolah serta dengan SEM (Structural Equation Modeling) untuk membuktikan asumsi model EKOP. Untuk menguji kecocokan antara model teoritis dengan data empiris, baik model pengukuran maupun model evaluasi didasarkan pada empat indikator, yaitu: 1) Chi-Square 2) @value; 3) RMSEA; dan 4) GFI. Pada analisis deskriptif, data kuantitatif yang diperoleh melalui instrumen penilaian dicari skor reratanya kemudian dikonversikan ke data kualitatif dengan skala 5, dan akhirnya dideskripsikan. Hasil deskripsi tersebut dijadikan sebagai dasar untuk menentukan model evaluasi yang dikembangkan beserta panduan dan perangkatnya. Konversi data kuantitatif ke data kualitatif dengan skala 5 menggunakan aturan yang merupakan modifikasi dari aturan yang dikembangkan oleh Sudijono (2003: 329 - 339). Aturan tersebut dapat dilihat dalam tabel berikut di bawah ini.

Tabel 2. Standar Konversi Data Kuantitatif ke Data Kualitatif

\begin{tabular}{|l|l|l|}
\hline \multicolumn{1}{|c|}{ Rerata Skor } & \multicolumn{1}{|c|}{ Klasifikasi } & \multicolumn{1}{c|}{ Kesimpulan } \\
\hline$>4,2$ & Sangat Baik & Dapat dijadikan contoh \\
\hline$>3,4-4,2$ & Baik & Dapat digunakan tanpa perbaikan \\
\hline$>2,6-3,4$ & Cukup & Dapat digunakan dengan sedikit perbaikan \\
\hline$>1,8-2,6$ & Kurang & Dapat digunakan dengan banyak perbaikan \\
\hline$\leq 1,8$ & Sangat Kurang & Belum dapat digunakan \\
\hline
\end{tabular}

\section{Hasil Pengembangan}

Setelah diadakan dua kali uji coba, satu kali uji implementasi dan tiga kali revisi terhadap instrumen dan panduan evaluasi model EKOP diperoleh hasil berikut ini. 


\section{Kejelasan Instrumen Kualitas Pembelajaran}

Penilaian terhadap kejelasan instrumen kualitas pembelajaran diperoleh hasil berikut:

\begin{tabular}{|c|l|c|}
\hline No. & \multicolumn{1}{|c|}{ Aspek Penilaian } & Rerata Skor \\
\hline 1 & Kejelasan petunjuk instrumen & 3,56 \\
\hline 2 & Kejelasan indikator kinerja guru dalam kelas & 3,64 \\
\hline 3 & Kejelasan indikator fasilitas pembelajaran & 3,52 \\
\hline 4 & Kejelasan indikator iklim kelas & 3,55 \\
\hline 5 & Kejelasan indikator sikap siswa & 3,64 \\
\hline 6 & Kejelasan indikator motivasi belajar & 3,65 \\
\hline 7 & Rumusan pernyataan yang komunikatif & 3,62 \\
\hline 8 & Penggunaan kalimat dan kata yang mudah dipahami & 3,65 \\
\hline 9 & Bentuk huruf & 3,64 \\
\hline 10 & Ukuran huruf & 3,64 \\
\hline 11 & Format atau layout & 3,62 \\
\hline \multicolumn{2}{|c|}{ Rerata Total Skor } & 3,62 \\
\hline
\end{tabular}

Rerata total skor 3,62 apabila dikonsultasikan dengan tabel standar konversi data kuantitatif ke kualitatif termasuk klasifikasi baik dan dapat dipergunakan tanpa perbaikan. Hasil penilaian tersebut menunjukkan bahwa instrumen pengumpulan data tentang kualitas pembelajaran IPS dapat dipahami dengan baik oleh responden. Dengan adanya pemahaman yang baik ini akan mengurangi kemungkinan adanya kesalahan maupun penafsiran ganda tentang isi instrumen yang pada akhirnya akan mengurangi tingkat validitas instrumen.

\section{Model Pengukuran Kualitas Pembelajaran}

Berdasarkan hasil analisis dengan CFA (confirmatory factor analysis) menggunakan Lisrel terhadap instrumen kualitas pembelajaran diperoleh hasil sebagai berikut: 
a) semua variabel tampak memiliki nilai muatan faktor $(\lambda)>0,30$ (kinerja guru $=0,61$; fasilitas pembelajaran $=0,52$; iklim kelas $=0,80$; sikap siswa $=0,56$; dan motivasi belajar siswa $=0,67$ ). Signifikansi paramater Lambda $X$ didasarkan pada batas minimal $>0,30$ menunjukkan bahwa besarnya parameter tersebut cukup signifikan dalam mengukur variabel laten, yaitu kualitas pembelajaran;

b) besarnya indikator fit model adalah: chi-Square $=15.77, \mathrm{df}=19, \mathrm{Q}^{-}$ value $=0.262$, RMSEA $=0.026 ;$ dan GFI $=0,99$. Hasil tersebut menunjukkan bahwa model pengukuran kualitas pembelajaran sudah sesuai antara konstruk teori dengan data lapangan karena memiliki pvalue $>0,05$; RMSEA < 0,08; dan GFI > 0,9. Dengan kata lain, model pengukuran kualitas pembelajaran tersebut merupakan model yang fit untuk mengumpulkan data tentang kualitas pembelajaran IPS.

\section{Kejelasan Instrumen Output Pembelajaran}

Penilaian terhadap kejelasan instrumen output pembelajaran diperoleh hasil berikut ini.

\begin{tabular}{|c|l|c|}
\hline No. & \multicolumn{1}{|c|}{ Aspek Penilaian } & Rerata Skor \\
\hline 1 & Kejelasan petunjuk instrumen & 3,58 \\
\hline 2 & Kejelasan indikator kecakapan memecahkan masalah & 3,61 \\
\hline 3 & Kejelasan indikator kecakapan bekerjasama & 3,64 \\
4 & Rumusan pernyataan yang komunikatif & 3,64 \\
\hline 5 & Penggunaan kalimat \& kata mudah dipahami & 3,68 \\
\hline 6 & Bentuk huruf & 3,68 \\
\hline 7 & Ukuran huruf & 3,72 \\
\hline 8 & Format atau layout & 3,64 \\
\hline \multicolumn{2}{|c|}{ Rerata Skor Total } & 3,65 \\
\hline
\end{tabular}

Rerata total skor 3,65 apabila dikonsultasikan dengan tabel standar konversi data kuantitatif ke kualitatif termasuk klasifikasi baik dan dapat dipergunakan tanpa perbaikan. Hasil penilaian tersebut menunjukkan bahwa instrumen pengumpulan data tentang output pembelajaran IPS dapat dipahami dengan baik oleh responden. Dengan adanya pemahaman yang 
baik ini akan mengurangi kemungkinan adanya kesalahan maupun penafsiran ganda tentang isi instrumen yang pada akhirnya akan mengurangi tingkat validitas instrumen.

\section{Model Pengukuran Output Pembelajaran}

Berdasarkan hasil analisis dengan CFA (confirmatory factor analysis) menggunakan Lisrel diperoleh hasil sebagai berikut:

a) semua variabel tampak memiliki nilai muatan faktor $(\lambda)>0,30$ (kecakapan akademik $=0,72$; kecakapan personal $=0,76$; kecakapan sosial $=0,71)$. Signifikansi paramater Lambda $X$ didasarkan pada batas minimal $>0,30$ menunjukkan bahwa besarnya parameter tersebut cukup signifikan dalam mengukur variabel laten, yaitu output pembelajaran IPS;

b) besarnya indikator fit model adalah: chi-square $=15.77, \mathrm{df}=19$, $\mathrm{Q}^{-}$ value $=0.262$, RMSEA $=0.026$; dan GFI $=0,99$. Hasil tersebut menunjukkan bahwa model pengukuran output pembelajaran sudah sesuai antara konstruk teori dengan data lapangan karena memiliki pvalue $>0,05$; RMSEA < 0,08; dan GFI > 0,9. Dengan kata lain, model pengukuran output pembelajaran tersebut merupakan model yang fit untuk mengumpulkan data tentang output pembelajaran IPS.

\section{Model Evaluasi}

Rerata skor hasil penilaian terhadap konsep model evaluasi program pembelajaran IPS disajikan pada tabel berikut ini.

\begin{tabular}{|c|l|c|}
\hline No. & \multicolumn{1}{|c|}{ Aspek Penilaian } & Rerata Skor \\
\hline 1 & Cakupan model EKOP & 4 \\
\hline 2 & Kepraktisan model EKOP & 4 \\
\hline 3 & Efisiensi penggunaan waktu evaluasi & 4 \\
\hline 4 & Efisiensi penggunaan biaya evaluasi & 4 \\
\hline 5 & Efisiensi penggunaan tenaga evaluasi & 4,08 \\
\hline \multicolumn{2}{|c|}{ Rerata Total Skor } & 4,02 \\
\hline
\end{tabular}

50 Sugeng Eko Putro Widoyoko 
Rerata total skor 4,02 apabila dikonsultasikan dengan tabel standar konversi data kuantitatif ke kualitatif evaluasi model EKOP termasuk klasifikasi model evaluasi yang baik, karena memiliki cakupan yang cukup komprehensif, praktis dan ekonomis dalam penggunaan, sehingga dapat digunakan untuk mengevaluasi program pembelajaran IPS di SMP.

Berdasarkan analisis SEM dengan Lisrel terhadap model EKOP diperoleh hasil sebagai berikut:

a) Semua variabel tampak memiliki nilai muatan faktor $(\lambda)>0,3$

b) Chi-Square $=15,77, d f=19, \varrho$-value $=0,26199(>0,05)$

c) RMSE $A$ sebesar $0,026(<0,08)$

d) $G F I=0,99(>0,90)$

Hasil analisis tersebut di atas menunjukkan bahwa model EKOP merupakan model fit atau tidak ada perbedaan model EKOP dengan data lapangan, sehingga dapat digunakan untuk mengevaluasi program pembelajaran IPS di SMP. Besarnya parameter gamma (indeks yang menyatakan efek langsung atau koefisien regresi) antara kualitas pembelajaran terhadap output pembelajaran dapat juga dilihat pada keluaran analisis Lisrel berikut ini.

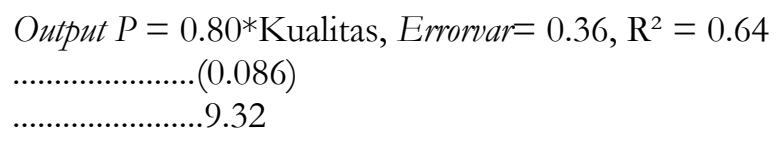

Keluaran Lisrel tersebut menunjukkan bahwa besarnya efek langsung kualitas pembelajaran IPS terhadap output pembelajaran IPS sebesar 0,80 cukup signifikan (bermakna) karena besarnya gamma $(\gamma)>0,3$ dan memiliki nilai t sebesar 9,32 (> 1,96). Dengan kata lain, kualitas pembelajaran IPS mempunyai pengaruh yang signifikan terhadap output pembelajaran IPS. Pengaruh $\left(\mathrm{R}^{2}\right)$ kualitas pembelajaran IPS terhadap output pembelajaran IPS adalah sebesar 64\%. Berdasarkan hasil analisis tersebut menunjukkan bahwa asumsi yang dijadikan sebagai dasar penyusunan model EKOP telah terbukti, yaitu bahwa kualitas pembelajaran mempengaruhi output pembelajaran. Dengan demikian untuk mempebaiki output pembelajaran tidak dapat berhasil secara maksimal tanpa memperbaiki kualitas pembelajaran yang telah berlangsung sebelumnya. 


\section{Panduan Evaluasi}

Penilaian terhadap panduan evaluasi diperoleh hasil berikut ini.

\begin{tabular}{|c|l|c|}
\hline No. & \multicolumn{1}{|c|}{ Aspek Penilaian } & Rerata Skor \\
\hline 1 & Kejelasan petunjuk umum & 4,08 \\
\hline 2 & Kejelasan langkah-langkah evaluasi & 4,08 \\
\hline 3 & Kejelasan rekomendasi hasil evaluasi & 4,08 \\
\hline 4 & Kejelasan waktu pelaksanaan evaluasi & 4,08 \\
\hline 5 & Rumusan pernyataan yang komunikatif & 4,08 \\
\hline 6 & Penggunaan kalimat dan kata yang mudah dipahami & 4 \\
\hline \multicolumn{2}{|c|}{ Rerata Total Skor } & 4,095 \\
\hline
\end{tabular}

Rerata total skor 4,095 apabila dikonsultasikan dengan tabel standar konversi data kuantitatif ke kualitatif panduan evaluasi model EKOP termasuk klasifikasi baik dan dapat dipergunakan. Berdasarkan hasil penilaian tersebut menunjukkan bahwa panduan evaluasi model EKOP cukup membantu pengguna model evaluasi dalam menggunakan model EKOP sehingga model EKOP menjadi lebih mudah untuk digunakan dalam mengevaluasi program pembelajaran IPS di SMP. Dengan adanya panduan tersebut diharapkan hasil evaluasi program pembelajaran IPS di SMP akan lebih cepat disampaikan kepada para pengguna hasil evaluasi program pembelajaran IPS, yaitu guru IPS, pimpinan sekolah maupun pihak-pihak lain yang berkepentingan dengan perbaikan pembelajaran IPS di SMP.

\section{Kesimpulan dan Rekomendasi}

Berdasarkan hasil analisis data dapat disimpulkan bahwa evaluasi model EKOP dinilai sebagai model yang cukup baik untuk mengevaluasi program pembelajaran IPS di SMP karena adanya hal-hal berikut ini.

1. Cakupan evaluasi cukup komprehensif, yaitu meliputi proses pembelajaran sekaligus output pembelajaran. Output pembelajaran tidak hanya kecakapan akademik, tetapi juga kecakapan personal dan 
kecakapan sosial. Cakupan evaluasi yang komprehensif akan mampu menghasilkan informasi yang lebih lengkap.

2. Instrumen pengumpulan data valid dan reliabel.

3. Hasil penilaian pemakai dan praktisi pembelajaran IPS menunjukkan bahwa: a) model EKOP dinilai cukup praktis dan ekonomis, b) panduan evaluasi dinilai cukup baik dan praktis sebagai acuan implementasi model di lapangan.

4. Panduan evaluasi yang cukup praktis dan model yang lebih sederhana sehingga akan lebih cepat dalam pengumpulan, pengolahan, dan penyampaian/penyajian informasi.

Berdasarkan kesimpulan di atas, dapat dirumuskan rekomendasi berikut ini.

1. Evaluasi model EKOP dapat dijadikan sebagai alternatif bagi pimpinan sekolah dalam melakukan evaluasi terhadap program pembelajaran IPS di SMP.

2. Evaluasi model EKOP dapat dikembangkan lebih lanjut agar menjadi lebih sempurna. Hal ini karena adanya keterbatasan pada fakta bahwa: a) aspek kecakapan personal belum memasukkan aspek percaya diri dan etos kerja yang dimiliki siswa dan b) belum melibatkan penilai independen (independent appraisal) dari luar.

3. Model EKOP menggunakan alur pikir yang sistemik dan sistematis. Oleh karena itu, akan lebih menarik lagi apabila model ini dapat dikembangkan lebih lanjut lewat pembuatan program komputer, sehingga pada akhirnya seorang evaluator hanya bertugas mengoreksi data yang ada dan mengentrinya ke dalam program. Selanjutnya tinggal mengambil print out dari komputer berupa data hasil evaluasi dan rekomendasi hasil evaluasi dalam rangka perbaikan program pembelajaran IPS.

\section{Daftar Pustaka}

Borg, W. R. \& Gall, M. D. (1983). Educational research: An Introduction. NewYork \& London: Longman 
Djemari Mardapi. (2000). Evaluasi pendidikan. Makalah disampaikan pada Konvensi Pendidikan Nasional tanggal 19 - 23 September 2000 di Universitas Negeri Jakarta.

Imam Ghozali \& Fuad. (2005). Structural equation modeling: Teori, konsep dan aplikasi dengan program Lisrel 8,54. Semarang: Badan Penerbit Universitas Diponegoro

Joreskog, K. \& Sorbom, D. 1996. Lisrel 8: User reference guide. Chicago. Scientific Software International.

Kirkpatrick, D. L. 1998. Evaluating training programs, The four levels (2 $2^{\text {nd }}$ ed.). San Francisco: Berrett-Koehler Publisher, Inc

Plomp,T. (1997). Development research on/in educational development. Netherlands: Twente University.

Solimun. (2002). Structural equation modeling (SEM) Lisrel dan Amos. Malang: Fakultas MIPA Universitas Brawijaya

Stufflebeam, D. L. \& Shinkfield, A.J. 1985. Systematic evaluation. Boston: Kluwer Nijhof Publishing.

Sudiyono, A. (2003). Pengantar evaluasi pendidikan. Jakarta: PT Raja Grafindo Persada

\section{Biodata Penulis}

Sugeng Eko Putro Widoyoko. Lahir di Batang, 13 Maret 1961. Lulus Sarjana Pendidikan program studi Pendidikan Dunia Usaha, IKIP Yogyakarta tahun 1986. Lulus Magister Pendidikan, program studi Pendidikan IPS, PPs UNY tahun 2003. Lulus Doktor Pendidikan, program studi PEP, konsentrasi Metodologi Evaluasi, PPs UNY, Januari 2008. Bekerja sebagai dosen Kopertis Wilayah VI Jawa Tengah dipekerjakan pada FKIP Universitas Muhammadiyah Purworejo sejak tahun 1987 sampai sekarang dengan pangkat terakhir Lektor Kepala/IV b. Telp. Rumah 0274 382918, HP 085868317318.

54 Sugeng Eko Putro Widoyoko 